\begin{tabular}{|l|l|l||}
\hline \multicolumn{2}{|c|}{ PublisherInfo } \\
\hline \hline PublisherName & $:$ & BioMed Central \\
\hline \hline PublisherLocation & $:$ & London \\
\hline \hline PublisherImprintName & $:$ & BioMed Central \\
\hline \hline
\end{tabular}

\title{
Genome complexity
}

\begin{tabular}{|l|l|l||}
\hline \multicolumn{2}{|c|}{ ArticleInfo } \\
\hline \hline ArticleID & $:$ & 4886 \\
\hline \hline ArticleDOI & $:$ & $10.1186 /$ gb-spotlight-20031124-01 \\
\hline \hline ArticleCitationID & $:$ & spotlight-20031124-01 \\
\hline \hline ArticleSequenceNumber & $:$ & 238 \\
\hline \hline ArticleCategory & $:$ & Research news \\
\hline ArticleFirstPage & $:$ & 1 \\
\hline \hline ArticleLastPage & $:$ & 3 \\
\hline \hline & & RegistrationDate : 2003-11-24 \\
ArticleHistory & $:$ & OnlineDate \\
\hline \hline ArticleCopyright & $:$ & BioMed Central Ltd2003-11-24 \\
\hline \hline ArticleGrants & $:$ & \\
\hline \hline ArticleContext & $:$ & 130594411 \\
\hline \hline
\end{tabular}




\section{Cathy Holding}

Email: cholding@hgmp.mrc.ac.uk

The question of whether the evolution of large and complex genomes in complex multicellular organisms is due to natural selection or simply a function of chance has been the subject of considerable debate. In November 21 Science, Michael Lynch and John Conery at Indiana University argue that the inclusion of intragenic spacers - introns - and transposons, coupled with the increase in gene number associated with genomes of multicellular animals and plants, were not essential for adaptive phenotypic diversification during eukaryotic evolution, but are the result of orders-of-magnitude reductions in population size. This process magnified random genetic drift and prevented 'purifying' natural selection from removing them (Science 2003, 302:1401-1404).

"Drawing from the now enormous databases provided by full-genome sequences, we have attempted to develop (and test) a general theoretical framework for explaining the expansion in genomic complexity (including numbers of genes, numbers and sizes of introns, and numbers of mobile elements) in the transitions from prokaryotes to unicellular eukaryotes to multicellular eukaryotes," Lynch told us in an e-mail.

"We are argue that much of the 'syndrome' of genomic complexity arose not because of direct selection for such change but because a reduction in population size diminishes the efficiency of natural selection against various types of genomic insertions," he said.

Laurence Hurst, professor of evolutionary genetics at the University of Bath explained, "If we ask the question why might a new mutation (a point mutation, an insertion, deletion, duplication, whatever) go from rare (which at first it must be) to common (aka, fixation), then, in principle, there are two answers: either selection favored it or it got there by chance (drift)," he told us by e-mail. "If a population is huge, it will take ages and many chance steps for a given new weakly deleterious mutation to get to fixation. In a small population, it takes just a few lucky steps."

The mathematics in the paper are based on the effective population size, $\mathrm{N}_{\mathrm{e}}$. "Generally, if the mutation reduces fitness by a small amount(s), then it will be eliminated if $s>>1 / \mathrm{N}_{\mathrm{e}}$. If $\mathrm{s}$ is about $1 / \mathrm{N}_{\mathrm{e}}$, it stands a pretty good chance of getting to fixation. So as $\mathrm{N}_{\mathrm{e}}$ goes up, an ever smaller number of slightly deleterious mutations can get to fixation by chance," Hurst wrote. "The authors say that as organisms get big, they also have low $\mathrm{N}_{\mathrm{e}}$. We have introns, but small eukaryotes do not, not because they are good for us but because our population size is too small for us to stop them accumulating."

Ian Dunham, senior investigator at the Sanger Institute commented, "The implication of this is that genome size is not dependent on genetic complexity, but much more so on nonselected processes. One implication is that carnivores should have larger genomes than herbivores. Another is that small animals should have smaller genomes than large animals."

Hurst added, "If small size means large population size (we typically suppose so on a grand scale), then small body size will lead to high $\mathrm{Ne}$, which will lead to more efficient counterselection and hence low genome size, by this model. But if you look at bat genomes, they seem to be smaller than those of rodents - suggesting ecology (flight demands, etc.) also plays a role. Birds also tend to have small genomes." 
Hurst added, "I think the remarkable thing about the paper is that such a simple model, ignoring many complexities, actually enables a pretty decent fit of theory to data."

"What I would like to see is the recombination rate eliminated as a covariable," he concluded.

\section{References}

1. Science, [http://www.sciencemag.org]

2. Indiana University, [http://www.indiana.edu/faculty/]

3. University of Bath, [http://www.bath.ac.uk/]

4. The Wellcome Trust Sanger Institute, [http://www.sanger.ac.uk]

This PDF file was created after publication. 